\title{
How to Shape the Employees' Organization Sustainable Green Knowledge Sharing: Cross-Level Effect of Green Organizational Identity Effect on Green Management Behavior and Performance of Members
}

\author{
Tai-Wei Chang ${ }^{1}$ and Cheng-Ze Hung ${ }^{2, *(D)}$ \\ 1 Graduate School of Resources Management and Decision Science College, National Defense University, \\ Taipei City 112, Taiwan; allain1105@yahoo.com.tw \\ 2 Department of Management, Air Force Institute of Technology, Kaohsiung County 82047, Taiwan \\ * Correspondence: clarinet8721@gmail.com
}

check for updates

Citation: Chang, T.-W.; Hung, C.-Z. How to Shape the Employees'

Organization Sustainable Green Knowledge Sharing: Cross-Level Effect of Green Organizational Identity Effect on Green Management Behavior and Performance of

Members. Sustainability 2021, 13, 626 https://doi.org/10.3390/su13020626

Received: 16 December 2020 Accepted: 8 January 2021 Published: 11 January 2021

Publisher's Note: MDPI stays neutral with regard to jurisdictional clai$\mathrm{ms}$ in published maps and institutional affiliations.

Copyright: $\odot 2021$ by the authors. Licensee MDPI, Basel, Switzerland. This article is an open access article distributed under the terms and conditions of the Creative Commons Attribution (CC BY) license (https:// creativecommons.org/licenses/by/ $4.0 /)$.

\begin{abstract}
In a period of rapid information development and response to the impact of environmentalism on the company, how to effectively promote organizational members embracing knowledge sharing behavior through knowledge management will be an important issue in corporate green management. This article proposes a new integrated multi-level research framework based on organizational identity theory and psychological ownership theory to further analyze enterprise green management. Utilizing the data of 73 supervisors and 583 subordinates in Taiwan's smallor medium-sized enterprises, results of the hierarchical linear modeling (HLM) analysis revealed that green group identification at the team level affects organizational members in terms of green product psychological ownership and green knowledge sharing as well as how green knowledge sharing, green creativity, and green product development performance are influenced when members get their green product psychological ownership. The results of the study validate the antecedents and consequences of green knowledge sharing and broaden the field of knowledge management for green management related to environmental behavior and performance, aside from providing valuable insights for relevant practitioners.
\end{abstract}

Keywords: green organizational identity; green product psychological ownership; green knowledge sharing; green creativity; green product development performance

\section{Introduction}

The modern business environment is changing rapidly in the 21st century. The consequential industrial upgrading and transformation as well as the rapid change in the economy have brought people to today's convenient life. However, many environmental problems have come with economic development that are deteriorating the environmental quality and may finally result in damage to ecological sustainability. Carbon emission reduction and global warming reduction have attracted attention from all over the world. Enterprises believe that any effort they make toward environmental improvement will improve their corporate image [1]. Furthermore, effectively promoting people's environmental intentions gives drivers more motivation to engage in environmental intent than those who have environmental knowledge [2]. On the other hand, along with the rising environmental protection awareness, environmental issues are gradually attracting the attention of people from all walks of life from international organizations to civil environmental groups. Management for encouraging green opportunities and green innovation should protect the environment from pollution and business models. Apart from maintaining corporate reputation and avoiding the punishment from environmental standard violations, active environmental management strategies could effectively develop new markets, improve environmental performance, and achieve competitive advantage [3]. 
According to the findings, consumers who are concerned about the environment are more willing to buy green products [4] and spend more on green products than others who are less concerned about the environment [5]. Xiao and Hong [6] also pointed out that environmental knowledge has a significant impact on personal environmental behaviors such as resource recycling or green consumption activities. With the emphasis on sustainable environmental development, green consumption has suddenly become the market development trend. Facing the pressure of the sustainable development of the environment, enterprises need to take initiative or be changeable. Instead, they should adopt integrated and active or innovative strategies such as product differentiation and cost reduction, respond positively to problems, and make improvements [7]. Brick and Lewis [8] also indicated that people will help members have an environmentally friendly behavior when they have personality traits focused on green issues. As far as companies are concerned how they can obtain the green approval [9] and initiative of their members [10], and improving the corporate green product development performance will be an essential key. Therefore, this research will focus on how to enhance green creativity and develop green product orientation that could meet the expectations of the public, create corporate own competitive advantages, and achieve sustainable development. In particular, creativity is the flame of innovation. Innovation involves the continuous course of production, utilization, and diffusion of knowledge. It could strengthen the enterprise core competence and consequently improve the corporate intelligence quotient when knowledge must be stored and utilized to construct the optimal strategy leverage through knowledge sharing and allocation [11]. Individual creativity performance should be improved and finally developed into technical creativity for the enterprise, which is a necessary process for an organization to reach the dominant position in competition [12].

In an economic system, human capital has become the major driving force for economic growth and industrial development. The employees' corporate technological creativity has also grown into a vital factor for enterprise development. Chen and Chang [13] pointed out that today's environmental management is most important for enterprises to build green ideas into the product development and design process. This approach creates a win-win situation for both enterprises and society. Among the environmental resources of an organization, "people" are the core organization resource because they play the most important role in the organizational competitive advantage to promote organizational performance [14]. Enterprises must develop environmental-friendly services and products that satisfy consumers with growing environmental consciousness [15]. Therefore, green creativity (GC) is significant for enterprises to maintain their competitive ability and one of the key parts for them to develop green products due to knowledge is a persistent competitive advantage [16]. According to RaudeliūNien, Davidavičienè, and Jakubavičius [17], knowledge management will be an effective tool for organizational efficiency improvement in the globalization and transformation environment. Knowledge sharing that helps an organization enhance intellectual capital and important resources and consequently to improve creativity and product development performance is a critical factor in the knowledge development and management process [18].

In the past, research on green product development performance $[9,10,19]$, green organization identity $[13,20]$, and green creativity [21,22] have focused on individual-level research. Green knowledge sharing issues could promote a contribution when the study adopts a multi-level research framework. Therefore, in order to fill this research gap, this study combined the theory of psychological ownership and organizational identity theory to explore the multi-level relationship of green management in enterprises. The relationship between green identification and enterprise members is discussed through the study of green knowledge sharing (GKS), GC, and green product development performance (GPDP) when front-line product $R \& D$ and sales employees get their green product psychological ownership (GPPO). Following the steps described below, this article first summarizes and explains the literature on GPPO, GKS, GC, GPDP, and green organizational identity (GOI). Next, this study conducted an empirical test to examine the relationship between these 
important variables. To be more specific, nine hypotheses were put forward and examined within the research framework. Finally, this article summarizes and discusses the findings, impacts, and possible directions of future research.

\section{Literature Review and Hypothesis Development}

2.1. Positive Effect of Green Product Psychological Ownership (GPPO) on Organizations and Staff Members

Psychological ownership refers to a situation in which the psychological ownership effects appear, causing people to regard a thing as their possession and extension [23-27]. For individuals, a thing integrated with that individual will be "mine" because it is regarded and accepted as their possession [28]. Etzioni [29] pointed out that ownership was characterized by "double creation", which involves attitude, object, spirit, and reality. In contrast, Pierce, Rubenfeld, and Morgan [30] believed that ownership was the presentation of a psychological course that was multivariate-oriented and formal (objective). It refers to the goal, or a part of the ownership is considered to be the condition of "theirs, mine, his, and ours", which all have the function of self-form (form and psychology) in the relationship between employee attitude and behavior ownership.

Porteous [31] put forward the three reasons for the formation of ownership satisfaction: (1) the ownership of control space itself; (2) the proposition of individualized exclusive space identity; and (3) the stimulation raised by, for example, thinking about, using, improving, or defending one's own possessions/fields. When people enhance place attachment, it will help to improve individual satisfaction with key psychological needs [32]. When the living environment is in a green space, it will help individuals feel satisfied with the quality of public places, the green space use frequency, and the improvement of mental health. The quality of public places and the frequency of green space use are key factors between social space and mental health [33]. According to relevant research for individuals working in an organization, the sense of achieving psychological ownership originates from four kinds of human needs: (1) efficacy and effectiveness; (2) self-identification; (3) having a place; and (4) stimulation, which are the incentive factors for the formation of psychological ownership. When efficacy and effectiveness are under an individual's control, a sense of ownership will arise in the heart for why it is used to measure satisfaction. Self-identification, where individuals prefer to achieve their ownership by experiencing, is regarded as a part of themselves and their self-extension. As a symbol of identification, it is most important to illustrate this through the recognition of others. Having a place refers to the need for personal space and home territory, which stimulates the individuals to take control of and throw themselves into their surroundings. Stimulation refers to the motivational force that intensifies, enhances, and awakens the individual's need of achieving the objects and drives individuals to think of, observe, care for, and maintain, just as people are motivated to seek stimulation to meet the need of awakening [34-37]. Jussila et al. [37] further put forward a model guided by the marketing concept about individual psychological ownership. The integration motive, the cause of psychological ownership, the object properties, and the psychological status are, respectively, described as follows: (1) efficacy and effectiveness, self-identification, having a place and stimulation; (2) the formative factors of antecedent: exercise of control, coming to know intimately and investment of the self; (3) the properties of the object: attractiveness, visibility, accessibility, manipulability, availability, and openness as well as the time and place for psychological ownership; and (4) result differentiation: motivational consequences, attitudinal consequences, and behavioral consequences.

According to Qian [38], as for the formation of psychological ownership, different formative directions lead to different emphases. For example, viewed from the perspective of form, psychological ownership mainly emphasizes the right of information acquisition, property right, and control power, whereas viewed from the perspective of organizational context, psychological ownership mainly emphasizes work design, the technical characteristics of working, leadership, and some other factors conducive to the formation of psychological ownership. The psychological ownership formative factors will not be lim- 
ited to a particular one. For example, when a business organization is taken as the object, psychological ownership will be influenced by its form and working characteristics as well as some other organizational factors such as organizational culture and climate, the attitude of top management, corporate goals, corporate vision, organizational reputation and company policies, corporate procedures, and so on [39].

Pierce et al. [34] pointed out that goal, as a part of the identity characteristics of psychological ownership, has its most important core: the sense of ownership and the sense of being psychologically related to the object, which means individuals feel the object of ownership (material or non-material characteristics) or a part of it is "theirs, ours, mine and his". The owner of ownership will treat it as a social entity, when a psychological connection is built between the object of ownership and its owner. The inside link between emotions and work will make employees become closer to their organization, generating more active and more positive attitudes and thoughts about their organization. These factors will combine to consequently improve the individual's work performance [40,41]. According to Pierce et al. [35], with the organization taken as the object, individuals are willing to take risks or make sacrifices for their organization, which is quite significant for members of the military, police, and fire organizations. Van Dyne and Pierce [42] also showed that psychological ownership will make a difference to an individual's attitude, motivation, and behavior. Such ownership is free from legal consequences, but it involves individual feelings, which is characterized by attitude, selfconcept, and the sense of responsibility. Mustafa, Ramos, and Man [43] successively stated that the enhanced individual responsibility to the enterprise organization will motivate extra-role care and protection behavior for the company when the organization is regarded as the object of psychological ownership. In conclusion, the strong sense of ownership will generate a positive attitude and idea, which will drive employees to conduct extra-role behavior to care for, protect, and take risks for it when the members regard their company's green products as the object of psychological ownership and obtain the psychological ownership of it.

With the global wave of environmental protection rising, enterprises must confront the increasingly more stringent regulations and the consumers' growing awareness of environmental protection. Therefore, the development of green product performance has become a key factor for enterprises to gain competitive advantages. Realizing the importance of environmental maintenance, most consumers choose to take direct resistance actions against irresponsible enterprises toward the environment. Therefore, environmental management factors should be incorporated in the development of new green products [44] that effectively cope with environmental challenges [45]. Moreover, Pujari et al. [44] pointed out that GPDP would play an important role in working out successful environmental strategies and assisting enterprises and economic entities to develop sustainable ecological development. Hunt and Morgan [46] pointed out that the excellent product development performance of an enterprise depended on how to transform individual creativity into concepts for the organization. Therefore, creativity is considered as an important influential factor for product development performance. Dahooie, Afrazeh, and Hosseini [47] pointed out that team member creativity would be affected by knowledge sharing among team members. Knowledge sharing is a process that can improve one's learning effect and also contribute to the improvement of creativity [16]. In the knowledge sharing process, someone spreads the information and knowledge that they know to others, which facilitates their learning and encourage others to learn, and finally creates synergy [48]. Therefore, knowledge sharing can promote the learning effect and enhance creativity [16]. In addition, some other relevant studies have also pointed out that when members regarded their organization as the object of psychological ownership, knowledge sharing would be positively related to their psychological ownership [49,50].

In conclusion, when employees take their company's green products as their object of psychological ownership, the generated sense of GPPO will inspire them to form positive and active attitude, thoughts, and performance. It is believed in this article that GPPO will 
contribute to the GKS between organizational members, their creativity, and GPDP. For this reason, this article puts forward the following hypotheses as follows:

Hypothesis 1 (H1). GPPO is positively related to green knowledge sharing (GKS).

Hypothesis 2 (H2). GPPO is positively related to green creativity (GC).

Hypothesis 3 (H3). GPPO is positively related to green product development performance (GPDP).

\subsection{Positive Effect of Green Knowledge Sharing (GKS) on Organizations and Its Staff Members}

Knowledge sharing refers to the knowledge supplier providing knowledge for the knowledge demander to help others to learn and develop new capabilities [51]. Knowledge sharing is a kind of transfer behavior realized in the learning process [52,53]. According to Hendricks [18], an organizational member shares knowledge with others while learning knowledge from them. Davenport and Prusak [16] believed that knowledge sharing was not simply an exchange of knowledge with each other, but helping team members find the knowledge they needed through the team knowledge exchange mechanism. Knowledge sharing benefits team creation. Nancy [48] believed that knowledge sharing transfers information and knowledge to others to create learning opportunities and encourage others to learn. This consequently generates the so-called synergy effect. In terms of the knowledge sharing attitude, Bock, Zmud, Kim, and Lee [54] pointed out that it meant the degree of one's positive emotion about knowledge sharing. Schwaer, Biemann, and Voelpel [55] expressed that knowledge sharing was a personal activity of providing or receiving knowledge and also a process of creating new knowledge together with each other. Knowledge sharing involves the exchange of task information and feedback on professional knowledge. This is helpful for working out new ideas, solving existing problems, and achieving the expected goals [56,57]. Knowledge sharing also involves the reception and transmission of knowledge among individuals [58]. Knowledge sharing requires a process to create knowledge performance such as knowledge utilization [59]. Therefore, knowledge will not come into full play and fall valueless if it fails to be communicated or shared [60]. In any event, the key to knowledge always lies in individuals, "people" in an organization will be the key factor in knowledge sharing and knowledge creation. Personal knowledge will change into organizational knowledge after being shared with other members in the organization, which is the exact point of organizational value promotion [61]. When the members of an organization become inspired through knowledge sharing, they can be motivated to work in new ways and put forward improved or creative ideas and strengthen their creativity $[16,62,63]$. As innovation comes from creative ideas, organizational innovation is the successful development and implementation of creative ideas inside the organization [64]. Knowledge sharing can encourage organizational knowledge exchange and increase creativity to ensure competitive advantage [65]. However, creativity refers to a process of realization that new things are created [66].

Knowledge sharing is considered not only the key part of encouraging employees' innovative behaviors and activities [67-69], but also the basic tool for stimulating critical thinking, and thus, upgrading ideas into innovation capability [70]. Internal knowledge sharing has a positive effect on the in-house strategy and will help shape the organizational innovative strategy [71]. Thornhill [72] also pointed out that knowledge is very important for the innovation process. To be innovative, employees have to acquire and exchange knowledge by interactions with each other. Sosa [73] showed that the knowledge sharing process among employees could improve personal professional knowledge and skills, gather creative ideas, and enhance others' or their own creativity to create better working performance. Knowledge sharing will help others develop effective action capability behavioral activities [51]. Therefore, knowledge sharing among organizational members will contribute to creativity $[47,74]$. Knowledge sharing can enhance individual creativity, which can be further applied to working performance improvement [75]. In this way, it can be seen that knowledge sharing has attracted 
increasingly more attention from academia and the business community. Having an influence on organizational performance, knowledge sharing has been regarded as a benchmark for measuring profitability and innovation practices [76]. How to enhance the employee's ability of intra-organizational knowledge sharing is very important for modern organizations. This is also one of the major challenges [16]. Thus, in such an atmosphere of environmental protection, enterprise knowledge sharing focused on environmental protection, and green issues will be considered as GKS. In this article, GKS is defined as the behavior that members of a company who are keen to pass on information and knowledge about green issues to others, promote learning opportunities and encourage others to learn, and create new knowledge for each other.

To conclude, it is believed that when staff members in a company are enthusiastic about sharing green knowledge and relevant green issues, it will contribute to corporate GC and GPDP. Therefore, some hypotheses were put forward as follows:

Hypothesis $4 \mathbf{( H 4 ) . ~ G K S ~ i s ~ p o s i t i v e l y ~ r e l a t e d ~ t o ~ g r e e n ~ c r e a t i v i t y ~ ( G C ) . ~}$

Hypothesis 5 (H5). GKS is positively related to green product development performance (GPDP).

\subsection{Positive Effect of Green Creativity (GC) on Green Product Development Performance (GPDP)}

Creativity is defined as the ability to produce a series of creative performance and products through professional skills [77], which can be reflected in a valuable and useful new product, service, idea, procedure, or process created by a group of people co-working in a complex social system [78]. Shalley and Gilson [79] further pointed out that creativity is a kind of ability to generate novel and potentially practical ideas about the products, actions, services, or procedures of an enterprise. Innovation is the successful implementation of novel ideas. Therefore, creativity is an important asset for enterprises and also one of the main sources of maintaining long-term competitive advantages [64,80,81]. Creativity is a critically decisive factor for new product development performance [82]. In such an environment-oriented society, combining creative thinking with the sustainable development concept has become significant to enterprise development [83]. As creativity has been regarded as the main driving force of innovation, enterprises should develop their organizational creativity to work out innovative solutions [84]. GC, which is considered to be original, novel, and practical, is the conceptual extension of green products, green services, green processes, and green practices [13]. For enterprises in today's world, GC is important as the cornerstone of green innovation implementation and development. Effective GC is able to help enterprises and society achieve sustainable environmental development [13], and even gain more competitive advantages by making a prompt response to the green trend [85]. In summary, GC in this article is defined as the behavior that integrates environment-related professional knowledge and creative and advanced thinking applied to products, services, processes, and the overall operation of enterprises in promoting the implementation of subsequent green innovation.

Hunt and Morgan [46] pointed out that an enterprise that is equipped with creative ideas will generate outstanding product development performance because the unique creativity in an innovative product development team can effectively respond to the variable needs of consumers, and consequently, create excellent product development performance [86]. According to the research by Chen, Chang, Lin, Lai, and Wang [10], GC is helpful for GPDP. Zhang and Li [87] also pointed out that green product development would benefit environmental protection and also serve as a strategy for enterprises to improve the added value of their products. Thus, to meet the consumers' increasingly frequent environmental demands in the environmental protection atmosphere, enterprises successively adopt green innovation strategies as its development goals, developing new green products to promote their enterprise's image, and continuously survive in the market. However, their GPDP depends on whether they have enough GC or not. According to Chen and Chang [13], GPDP can be seen as "the products created are made from or partially 
from renewable materials in a more energy-saving way, and will have less influence on the environment and be less harmful to human health when they are supplied to the market with more compact packing". If an enterprise aims to successfully develop green products, it must integrate the idea of green thinking into green product development activities [83]. A green product can be produced and consumed with minimal environmental impact [87].

Thus, in the age filled with an environmental protection political atmosphere, enterprises strengthen the GPPO of staff members to meet consumers' increasingly rising pursuit of environmental protection, which will contribute to the positive and active GKS of employees. Employees will be inspired to take GC as their strategic development goal and improve their GC and green product performance. Therefore, this article puts forward some hypotheses as follows:

Hypothesis 6 (H6). GC is positively related to GPDP.

Hypothesis 7 (H7). GKS mediated the relationship between GPPO and GC, GPDP.

Hypothesis 7a (H7a). GKS mediated the relationship between GPPO and GC.

Hypothesis $\mathbf{7 b} \mathbf{( H 7 b ) . ~ G K S ~ m e d i a t e d ~ t h e ~ r e l a t i o n s h i p ~ b e t w e e n ~ G P P O ~ a n d ~ G P D P . ~}$

\subsection{Positive Effect of Green Organizational Identity (GOI) on Staff Members}

Organizational identity can be regarded as the collective cognitive framework of an organization that influences the organization's interpretation process as well as its members' cognition and actions [88,89]. From a social interaction perspective, individuals and the environment are mutually influenced. An individual's behavior will be interactively influenced by both the behavior itself and the environmental factors [90], which also means that individual behavior is not alone in the organizational operation, but generated under the influence of the overall organizational environment during the interactions between individuals and the environment [91]. According to Byron [92], the influential factors of the relationship between work and life can be roughly divided into three aspects: work-related, non-work-related, and personal. In other words, in addition to the individual influence, the personal perception of the organization will also be a part of work-related influential factors. Ashforth and Mael [93] pointed out that organizational identity has a significant impact on the attitude and effectiveness of organizational members. Organizational members with a high degree of organizational identity will be more cooperative, leading to higher organization competitiveness. Cheney [94] also believed that organizational identity was related to the members' work motivation, work performance, and the achievement of organizational goals. In addition, organizational identity can also contribute to the members' extra-role behaviors [95,96]. Organizational identity has a positive impact on knowledge sharing [97], and team identification will contribute to knowledge sharing behavior [98]. Sethi [99] also expressed that in the formative process of innovation, organizational identity would positively enhance innovation performance. The integration of organizational identity can promote innovation through combining the different knowledge structures inside the organization [100]. Within an environmental management interpretive framework related to the maintenance and protection of the environment, something that organizational members jointly construct and make their behaviors meaningful, is called green organizational identity (GOI) [20]. With the same GOI, the members of the organization will be motivated to form a new cognition of environmental issues, work out meaningful thoughts on the relationship between new environmental technologies and consumer demands, and consequently, advance innovation in more creative ways [101]. Geraie and Rad [102] pointed out that in today's society, where great importance has been attached to environmental issues, green organization identity would ensure organizational competitive advantages and increase the quality and quantity of organizational innovation and competitiveness. 
In short, GOI will help organizational members understand how individual tasks are related to the enterprises' environmental activities and strengthen the enterprises ${ }^{\prime}$ ability to understand and cope with green-oriented business conditions. Therefore, when environmental protection and enterprise greening are brought into enterprise goals, the framework of the members' organizational identity is greened, which will bring meaning to enterprise environmental management activities and individual environmentally-friendly behaviors, and inspire members to bring GKS into their extra-role behaviors. Thus, this article puts forward some hypotheses as follows:

Hypothesis 8 (H8). GOI is positively related to GPPO.

Hypothesis 9 (H9). GOI is positively related to GKS.

Based on the previous hypotheses and relevant studies, this article summarizes the research framework (see Figure 1) and uses psychological ownership to further discuss the positive influence that GOI imposes on GPPO and knowledge sharing. In addition, GPPO has a positive influence on GKS, GC, and green product development performance. With GKS serving as an intermediary agent, nine hypotheses are put forward in this article.

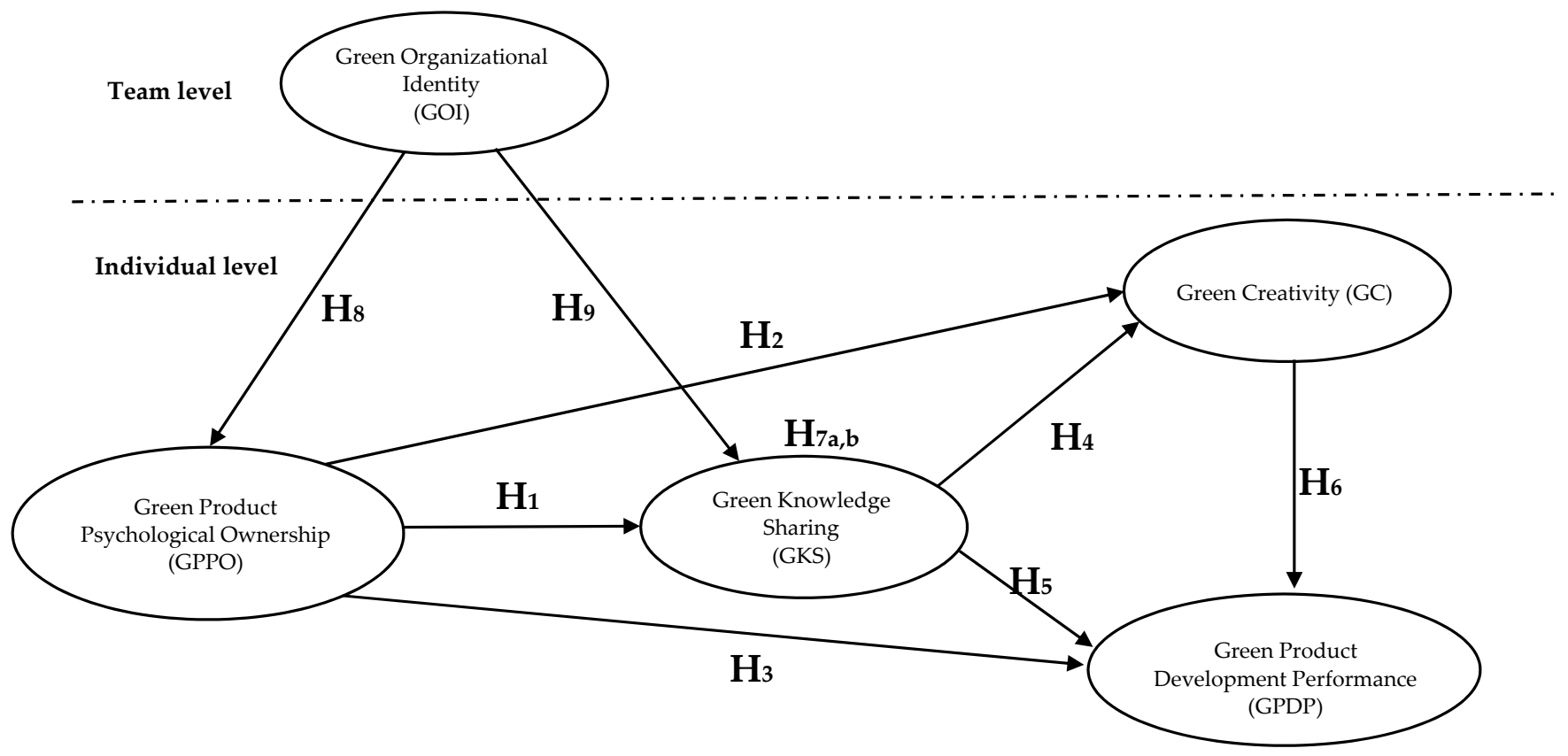

Figure 1. Research framework.

\section{Methodology and Measurement}

\subsection{Data Collection and Sample}

We conducted questionnaires to examine these hypotheses in the different industries of Taiwan including electronic information industry, trading companies, department stores, tourism, catering, and leisure industries based on the "Business Directory of Taiwan". The survey was distributed by convenience sampling. These interviewees were the first-line supervisors and employees of $R \& D$ and sales departments because they are involved in the specific environmental product development project that accounted for the most revenue of their enterprise. Each respondent was subsequently required to consider environmental product development projects as the key point to validate the GPPO, GKS, GC, GPDP, and GIO of the project team. Maas and Hox [103] suggested that a group size of five members was sufficient in cross-level research and seventy-three team questionnaires, which had 8-10 questionnaires for each team, were issued. 
We received 803 surveys, out of which 583 matched surveys were complete for a $72.6 \%$ return rate with participant responses from first-line employees and their supervisor. To have a highly effective response rate, we only sent questionnaires and gifts to companies that had the help of relevant personnel to green product development projects and sell green products as their main products. Most respondents were male (78.9\%). In terms of educational level, $66.4 \%$ of the respondents graduated from graduate school and $20.2 \%$ from a four-year college. In terms of marriage, $69.6 \%$ of the respondents were married and $30.4 \%$ of the respondents were unmarried. The distribution of industry in the current employment was across the following categories: electronic information industry (39\%), trading companies (25\%), and tourism (36\%). In summary, the respondents were mostly male, highly educated, married, and in the electronic information industry.

\subsection{Definitions and Measurements of the Constructs}

The questionnaire for this study included five measurement perspectives such as GOI, GPPO, GKS, GC, and GPDP. The questionnaire was developed according to the advice of relevant scholars (Appendix A), and the questionnaire items were rated on a 7-point Likert scale ranging from rank 1 (never) to rank 7 (often), where a higher score means a higher degree of the constructs. Respondents were asked to tick the relevant checkboxes. The Cronbach's alpha between the constructs was $0.915-0.975$. The details are as follows:

Green Organizational Identity. GOI is defined as "Within an environmental management interpretive framework related to the maintenance and protection of the environment, something that organizational members jointly construct and make their behaviors meaningful is called GOI [20]." The GOI scale developed by Chen [20] was used in this article. Six test items were used mainly to measure the GOI degree of organizational members. The Cronbach's alpha was 0.975.

Green Product Psychological Ownership. GPPO is defined as "when employees take their company's green products as their object of psychological ownership, the generated sense of GPPO will inspire them to form a positive and active attitude, thoughts, and performance." The Psychological Ownership Scale developed by Chang [41] was adopted in this article. Three test items were mainly used to measure the degree of the organizational members' sense of GPPO and the Cronbach's alpha was 0.938 .

Green Knowledge Sharing. GKS is defined as "GKS is defined as the behavior that members of a company who are keen to pass on personal own information and knowledge about green issues to others, promote learning opportunities and encourage others to learn, and create new knowledge for each other." The Knowledge Sharing Scale developed by Bock et al. [54] was adopted in this article. There were five test items used mainly to measure the GKS degree of organizational members and the Cronbach's alpha was 0.942.

Green Creativity. GC is defined in this article is defined "as the behavior that integrates environment-related professional knowledge and creative and advanced thinking applied to products, services, processes, and the overall operation of enterprises in promoting the implementation of subsequent green innovation." The GC Scale developed by Chen and Chang [13] was used in this article. Six test items were mainly used to measure the GC degree of organizational members and the Cronbach's alpha was 0.959.

Green Product Development Performance. GPDP is defined as "the products created are made from or partially from of renewable materials in a more energy-saving way, and will have less influence on the environment and be less harmful to human health when they are supplied to the market with more compact packing." The GPDP Scale developed by Chen and Chang [13] was adopted in this article. Eight test items were mainly used to measure the degree of organizational GPDP and the Cronbach's alpha was 0.915.

\section{Empirical Results}

\subsection{Measurement Model Results}

Table 1 shows the means, standard deviations, min (max) values, correlations, and average variance extracted (AVE) mean square root of the constructs in this article. The 
table shows that the constructs were positively related with each other at the individual level.

Table 1. Means, standard deviations, $\min (\max )$ values, correlations, and average variance extracted (AVE) mean square root of the constructs.

\begin{tabular}{|c|c|c|c|c|c|c|c|c|}
\hline Constructs & Mean & Standard Deviation & Min. & Max. & A. & B. & C. & D. \\
\hline \multicolumn{9}{|l|}{ Team level } \\
\hline GOI & 4.667 & 1.293 & 1.00 & 7.00 & & & & \\
\hline \multicolumn{9}{|c|}{ Individual level } \\
\hline A. GPPO & 4 & 1.264 & 1.00 & 7.00 & $(0.915)$ & & & \\
\hline B. GKS & 5 & 1.066 & 1.00 & 7.00 & $0.241^{* *}$ & $(0.877)$ & & \\
\hline C. GC & 5 & 1.066 & 1.00 & 7.00 & $0.428^{* *}$ & $0.284^{* *}$ & $(0.893)$ & \\
\hline D. GPDP & 4 & 1.054 & 1.00 & 7.00 & $0.245^{* *}$ & $0.231 * *$ & $0.430^{* *}$ & $(0.827)$ \\
\hline
\end{tabular}

Notes: (1) Diagonal elements are the square roots of AVE; (2) ${ }^{* *}: p<0.01$; (3) green organizational identity (GOI); green product psychological ownership (GPPO); green knowledge sharing (GKS); green creativity (GC); green product development performance (GPDP).

Each construct factor was analyzed as shown in Table 2. There were, respectively, six, three, five, five, and five items for GOI, GPPO, GKS, GC, and GPDP, respectively. Only one factor could be extracted from each construct, and each cumulative percentage of explained variance was more than $61 \%$. Therefore, it was not necessary to divide them into two constructs.

Table 2. Factor analysis of this study.

\begin{tabular}{cccc}
\hline Constructs & Number of Items & Number of Factors & $\begin{array}{c}\text { Accumulation Percentage } \\
\text { of Explained Variance }\end{array}$ \\
\hline $\begin{array}{c}\text { Team level } \\
\text { GOI }\end{array}$ & 6 & 1 & $89.095 \%$ \\
Individual level & 3 & 1 & $89.042 \%$ \\
GPPO & 5 & 1 & $81.453 \%$ \\
GKS & 5 & 1 & $61.0 \%$ \\
GC & 5 & 1 & $74.638 \%$ \\
GPDP & 5 & & \\
\hline
\end{tabular}

Note: green organizational identity (GOI); green product psychological ownership (GPPO); green knowledge sharing (GKS); green creativity (GC); green product development performance (GPDP).

As Table 3 shows, the items' loads $(\lambda)$ and the constructs' Cronbach's $\alpha$ coefficients, CR values, and AVEs all conformed to standard values individually stated as follows: Cronbach's $\alpha$ was used to analyze and explain the credibility of each construct. According to Hair, Anderson, Tatham, and Black [104], the Cronbach's $\alpha$ is required to be above 0.7. The Cronbach's $\alpha$ of each construct in this article was, respectively, 0.975, 0.938, 0.942, 0.959, and 0.915 , which all met that requirement on the Cronbach's $\alpha$. Thus, the credibility of the questionnaire conforms to standard. Composite reliability, CR, was used to analyze and explain the internal consistency of every construct variable. According to Bagozzi and $\mathrm{Yi}$ [105], the CR is required to be above 0.7. Additionally, the CR of each construct in this article was, respectively, $0.965,0.939,0.943,0.959$, and 0.915 , which all met that requirements on the $C R$ value. Thus, the questionnaire was internally consistent. Convergent validity is used to analyze and explain the convergent validity of every construct. According to Fornell and Larcker [106], AVE is used to measure the potential variable value about the percentage of measurable variables, which is required to not be less than 0.5 . The discriminant validity standard is that the mean square root of AVE is required to be more than the relevant coefficient between each perspective. Table 3 shows that the AVE value of each construct in this article was, respectively, $0.965,0.939,0.943,0.959$, and 0.915 , which were all above 0.5. Another table shows that the mean square root of AVE for each construct is more than the relevant coefficient between each perspective. Thus, the convergent validity of this questionnaire conforms to the standard and has discriminant validity. Shown in the above 
results, the credibility and validity of the scale used for this study conform to the relevant standards and requirements.

Table 3. The items' loads $(\lambda)$ and the constructs' Cronbach's $\alpha$ coefficients and AVEs.

\begin{tabular}{|c|c|c|c|c|c|c|}
\hline Constructs & $\begin{array}{l}\text { Items } \\
\text { Number }\end{array}$ & $\begin{array}{c}\text { Factor } \\
\text { Loading }(\lambda)\end{array}$ & Cronbach's $\alpha$ & CR & AVE & $\begin{array}{l}\text { The Square } \\
\text { Root of AVE }\end{array}$ \\
\hline \multicolumn{7}{|l|}{ Team level } \\
\hline \multirow{6}{*}{ GOI } & GOI1 & 0.925 & \multirow{6}{*}{0.975} & \multirow{6}{*}{0.965} & \multirow{6}{*}{0.82} & \multirow{6}{*}{0.905} \\
\hline & GOI2 & $0.928^{* * *}$ & & & & \\
\hline & GOI3 & $0.909^{* * *}$ & & & & \\
\hline & GOI4 & $0.865^{* * *}$ & & & & \\
\hline & GOI5 & $0.904^{* * *}$ & & & & \\
\hline & GOI6 & $0.899^{* * *}$ & & & & \\
\hline \multicolumn{7}{|l|}{ Individual level } \\
\hline \multirow{3}{*}{ GPPO } & GPPO1 & 0.886 & \multirow{3}{*}{0.938} & \multirow{3}{*}{0.939} & \multirow{3}{*}{0.837} & \multirow{3}{*}{0.915} \\
\hline & GPPO2 & $0.940^{* * *}$ & & & & \\
\hline & GPPO3 & $0.917^{* * *}$ & & & & \\
\hline \multirow{5}{*}{ GKS } & GKS1 & 0.816 & \multirow{5}{*}{0.942} & \multirow{5}{*}{0.943} & \multirow{5}{*}{0.7692} & \multirow{5}{*}{0.877} \\
\hline & GKS2 & $0.896^{* * *}$ & & & & \\
\hline & GKS3 & $0.891^{* * *}$ & & & & \\
\hline & GKS4 & $0.869^{* * *}$ & & & & \\
\hline & GKS5 & $0.910^{* * *}$ & & & & \\
\hline \multirow{6}{*}{ GC } & GC1 & 0.882 & \multirow{6}{*}{0.959} & \multirow{6}{*}{0.959} & \multirow{6}{*}{0.797} & \multirow{6}{*}{0.893} \\
\hline & GC2 & $0.886^{* * *}$ & & & & \\
\hline & GC3 & $0.902^{* * *}$ & & & & \\
\hline & GC4 & $0.907^{* * *}$ & & & & \\
\hline & GC5 & $0.886^{* * *}$ & & & & \\
\hline & GC6 & $0.893^{* * *}$ & & & & \\
\hline \multirow{5}{*}{ GPDP } & GPDP1 & 0.767 & \multirow{5}{*}{0.915} & \multirow{5}{*}{0.915} & \multirow{5}{*}{0.5187} & \multirow{5}{*}{0.72} \\
\hline & GPDP2 & $0.845^{* * *}$ & & & & \\
\hline & GPDP3 & $0.871^{* * *}$ & & & & \\
\hline & GPDP4 & $0.819^{* * *}$ & & & & \\
\hline & GPDP5 & $0.828^{* * *}$ & & & & \\
\hline
\end{tabular}

Notes: $(1)^{* * *} p<0.001$; (2) green organizational identity (GOI); green product psychological ownership (GPPO); green knowledge sharing (GKS); green creativity (GC); green product development performance (GPDP).

\subsection{Structural Model Results}

The structural equation modeling (SEM) statistical analysis method was adopted to examine the hypotheses at the individual level and analyze the data materials, realized through AMOS statistical analysis software (26.0). Cross-level hypotheses were examined through HLM (7.02) statistical analysis software.

To ensure that the variable sample at the team level was appropriate, this article first conducted null model GPPO testing and knowledge sharing to calculate the ICC (1) and ICC (2) values of the variables. James [107] suggested that the ICC standard (1) should be greater than 0.12, and the ICC (2), according to Glick [108] and Qstroff and Schmitt [109], should be greater than 0.6. The result shows that GPPO did not reach the standard, so the rating of organizational employees was very consistent [107]. Therefore, it is appropriate to aggregate the organizational identity of knowledge sharing samples to the team level. The next was to test the rwg value. George and Bettenhausen [110] suggested that the rwg standard should be greater than 0.7 . The result showed that the rwg value was 0.8364 , which was worked out using the median operation and 0.7805 by the average operation.

Second, the SEM statistical analysis method was used for the model analysis at the individual level. Figure 2 presents the results for the full model at the individual level: $\mathrm{GFI}=0.918$, RMSEA $=0.063$, AGFI $=0.893$, and CFI $=0.968$, which indicates that the overall modeling fitness reached the standard. The coefficient of each path was, respectively, 
0.397 for $\mathrm{H} 1,0.282$ for $\mathrm{H} 2,0.113$ for $\mathrm{H} 3,0.186$ for $\mathrm{H} 4,0.089$ for $\mathrm{H} 5$, and 0.4 for H6, each of which reached the significant level.

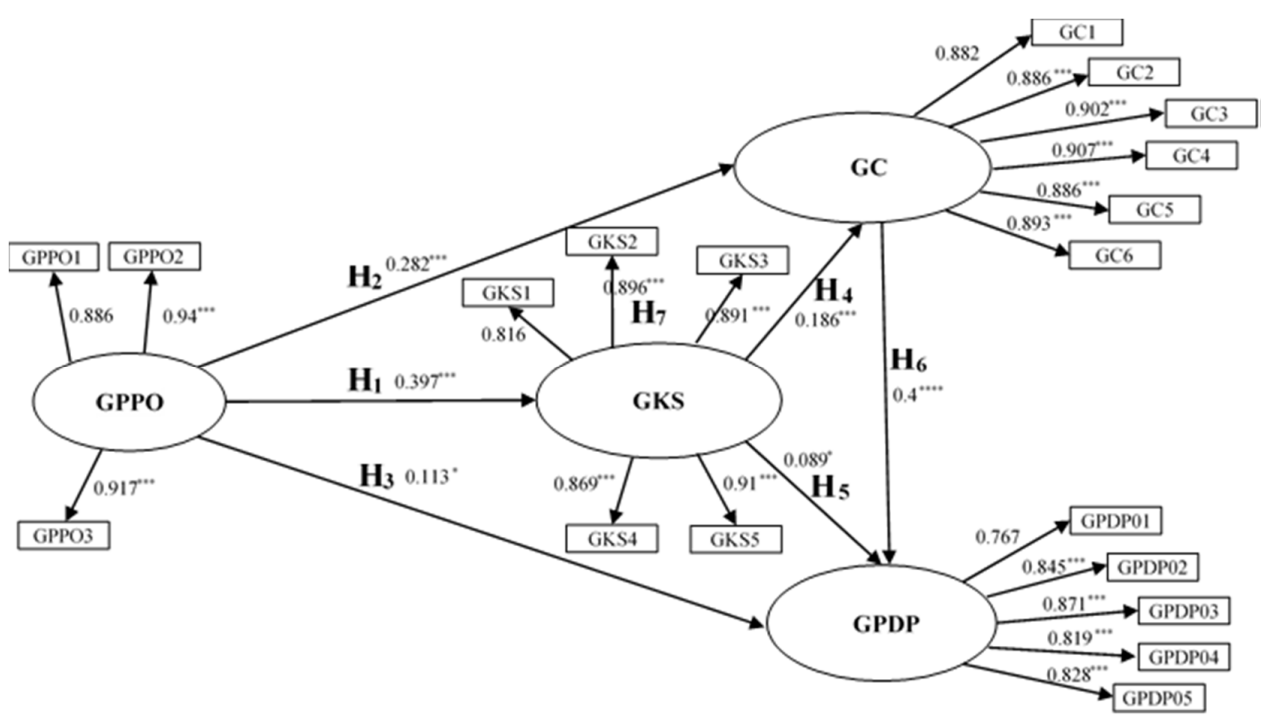

$\mathrm{GFI}=0.918, \mathrm{RMSEA}=0.063, \mathrm{AGFI}=0.893, \mathrm{CFI}=0.968$. Note: ${ }^{*} p<0.05,{ }^{* * *} p<0.001$

Figure 2. Individual-level full model results.

From the above-mentioned details, GPPO has a positive direct relation with GC, GKS and GPDP, and the GKS also has a positive direct relation with GC and GPDP. In accordance with the mediating effect validation put forward by Baron and Kenny [111], GKS serves as an intermediary agent between GPPO and GC or GPDP. In this article, the bootstrapping method by Taylor, MacKinnon, and Tein [112] was further used to test the mediating effect, for which 5000 bootstrap samples were taken to perform percentile bootstrap and offset correction percentile bootstrap with a $95 \%$ confidence interval. According to the results shown in Table 4, GKS was proven to play a significantly positive mediating role between GPPO and GC (the standardized indirect effect was 3.083; standardized direct effect was 4.78; and each $Z$ was over 1.96) as well as between GPPO and GPDP (standardization indirect effect, 5.71; standardized direct effect, 2.173; and each $Z$, over 1.96). Therefore, it can be concluded that GPPO has a partially mediating effect between GC and GPDP.

Table 4. The mediation results of GKS using confidence interval bootstrap.

\begin{tabular}{|c|c|c|c|c|c|c|c|}
\hline & \multirow{3}{*}{$\begin{array}{c}\text { Point } \\
\text { Estimation }\end{array}$} & & & \multicolumn{4}{|c|}{ Bootstrapping } \\
\hline & & \multicolumn{2}{|c|}{ Product of Coefficients } & \multicolumn{2}{|c|}{$\begin{array}{c}\text { Bias-Corrected } \\
95 \% \text { CI }\end{array}$} & \multicolumn{2}{|c|}{$\begin{array}{c}\text { Percentile } \\
95 \% \text { CI }\end{array}$} \\
\hline & & S.E. & $\mathbf{Z}$ & Lower & Upper & Lower & Upper \\
\hline \multicolumn{8}{|c|}{ Standardized Total Effect } \\
\hline GPPO -> GC & 0.356 & 0.052 & $6.846^{* * *}$ & 0.25 & 0.454 & 0.25 & 0.454 \\
\hline GPPO -> GPDP & 0.291 & 0.047 & $6.191^{* * *}$ & 0.198 & 0.379 & 0.198 & 0.379 \\
\hline \multicolumn{8}{|c|}{ Standardized Indirect Effect } \\
\hline GPPO -> GC & 0.074 & 0.024 & $3.083^{* *}$ & 0.033 & 0.128 & 0.03 & 0.124 \\
\hline GPPO -> GPDP & 0.177 & 0.031 & $5.71^{* * *}$ & 0.121 & 0.245 & 0.117 & 0.24 \\
\hline \multicolumn{8}{|c|}{ Standardized Direct Effect } \\
\hline GPPO -> GC & 0.282 & 0.059 & $4.78^{* * *}$ & 0.165 & 0.395 & 0.165 & 0.394 \\
\hline GPPO -> GPDP & 0.113 & 0.052 & $2.173 *$ & 0.012 & 0.218 & 0.011 & 0.218 \\
\hline
\end{tabular}

Notes: (1) Standardized estimating of 5000 bootstrap sample; (2) ${ }^{* * *}: \mathrm{Z}>3.29,{ }^{* *}: \mathrm{Z}>2.58,{ }^{*}: \mathrm{Z}>1.96$; (3) $\mathrm{N}=583$; (4) green knowledge sharing (GKS); green product psychological ownership (GPPO); green creativity (GC); green product development performance (GPDP). 
The results of this study found that GPPO, which is an important antecedent variable, has a significantly positive effect on GKS, GC, and GPDP at the individual level, whereas GKS plays an intermediary role, and the team-level GOI will have a significant effect on the individual-level GKS. Table 5 shows that all of the nine hypotheses had a significant effect. After further data examination, it was unexpectedly discovered that GPPO could impose some influence on GPDP through GKS and GC $(t=3, t>1.96)$. The total effect, indirect effect, and direct effect of the $95 \%$ confidence interval proposed by bias-corrected and percentile; zero was not included between the lower limit and the upper limit, which can work as a long-distance intermediary agent.

Table 5. Results of the structural model.

\begin{tabular}{|c|c|c|c|c|c|c|c|c|}
\hline \multicolumn{9}{|c|}{ Individual Level Relations } \\
\hline Hypothesis & \multicolumn{5}{|c|}{ Path Coefficient } & \multicolumn{2}{|c|}{ Z Value } & Results \\
\hline $\mathrm{H} 1$ & \multicolumn{5}{|c|}{$0.397^{* * *}$} & & & $\mathrm{H} 1$ is supported \\
\hline $\mathrm{H} 2$ & \multicolumn{5}{|c|}{$0.282 * * *$} & & & $\mathrm{H} 2$ is supported \\
\hline H3 & \multicolumn{5}{|c|}{$0.113 *$} & & & $\mathrm{H} 3$ is supported \\
\hline $\mathrm{H} 4$ & \multicolumn{5}{|c|}{$0.186^{* * *}$} & & & H4 is supported \\
\hline H5 & \multicolumn{5}{|c|}{$0.089 *$} & & & H5 is supported \\
\hline H6 & \multicolumn{5}{|c|}{$0.4^{* * *}$} & & & H6 is supported \\
\hline \multicolumn{9}{|c|}{ Mediates the Relations } \\
\hline $\mathrm{H} 7 \mathrm{a}$ & \multicolumn{5}{|c|}{ GPPO -> GKS -> GC } & \multicolumn{2}{|c|}{$3.083 * *$} & $\mathrm{H7}$ is supported (completely \\
\hline $\mathrm{H7b}$ & \multicolumn{5}{|c|}{ GPPO -> GKS -> GPDP } & \multicolumn{2}{|c|}{$5.71^{* * *}$} & mediating) \\
\hline Study found & \multicolumn{5}{|c|}{ GPPO $->$ GKS $->$ GC $->$ GPDP } & \multicolumn{2}{|c|}{$3^{* * *}$} & Distal indirect effect \\
\hline \multicolumn{9}{|c|}{ Cross-Level Relations } \\
\hline \multirow{3}{*}{ Hypothesis } & \multicolumn{2}{|c|}{ GPPO } & \multicolumn{2}{|c|}{ GKS } & \multirow{2}{*}{\multicolumn{2}{|c|}{$\frac{\text { GOI }}{\mathbf{r}_{\mathrm{wg}}}$}} & \multirow{3}{*}{ t Value } & \multirow{3}{*}{ Results } \\
\hline & \multirow{2}{*}{$\operatorname{ICC}(1)$} & \multirow{2}{*}{$\operatorname{ICC}(2)$} & \multirow{2}{*}{$\operatorname{ICC}(1)$} & \multirow{2}{*}{$\operatorname{ICC}(2)$} & & & & \\
\hline & & & & & Average & Mean & & \\
\hline $\begin{array}{l}\mathrm{H} 8 \\
\mathrm{H} 9\end{array}$ & 0.296 & 0.771 & 0.189 & 0.651 & 0.781 & 0.836 & $\begin{array}{c}2.9^{* *} \\
6.574^{* * *}\end{array}$ & $\begin{array}{l}\text { H8 is supported } \\
\text { H9 is supported }\end{array}$ \\
\hline
\end{tabular}

Notes: $(1)^{*}: p<0.05,{ }^{* *}: p<0.01,{ }^{* * *}: p<0.001 ;(2)$ green product psychological ownership (GPPO); green knowledge sharing (GKS); green creativity (GC); green product development performance (GPDP); (3) ICC(1) > 0.12, ICC(2) > 0.6; (4) rwg > 0.6.

\section{Conclusions and Implications}

\subsection{Theoretical Implications}

This study mainly tried to focus on knowledge management of environmental issues, given that knowledge is a significant resource for learning new affairs, solving problems, and creating core competitiveness [65]. Therefore, knowledge sharing is the key to the success of knowledge management [113]. This article tried to explore the cross-level research framework of how the GPPO of organizational members is related to their GKS, GC, and GPDP [9] and the team-level effect of GOI. This research expands the field of knowledge management for green management related to environmental behavior and performance.

The results show that: (1) GPPO has a positive effect on GKS, GC, and GPDP; (2) GC has a positive effect on GPDP; (3) GKS plays a mediator in the relation between GPPO and GC or GPDP; and (4) green organization identification has a positive effect on GPPO and GKS among organization members. Organizational identity can help improve GKS among organization members, intensify the degree of GPPO, and consequently improve the GC and GPDP of organizational members. For those reasons, enterprises are supposed to strengthen the degree of GPPO among organization members and encourage GKS behavior to motivate GC and GPDP.

This study made four academic contributions to the literature. First, this article examined the relationship between GC and GPDP [10] and extended the knowledge management model as an intermediary agent and antecedent variable to integrate other 
variables (such as GPPO and GKS). Second, this research found a gap on how GC and GPDP were related to the employees' innovative behaviors in a limited way. The result showed that GKS will have a significant impact on GC and GPDP because the first-line employees from the companies' sales and R\&D departments would care about consumers. Third, GKS was proven to be an important mediator between organizational employees' GPPO and their GC and GPDP, which highlighted the synergism of GKS for the GC and product development performance of the organizational members. Finally, psychological ownership has a very important influence on the behavior of organizational members. Therefore, organizations are supposed to encourage GKS behavior between organizational members and improve their GC and GPDP through intensifying the degree of their GPPO.

\subsection{Managerial Implications}

The results of this study suggest three practices for GPDP. First, knowledge management is one of the key factors in enterprise success to encourage GKS between organizational members in a period of knowledge and information. Company policies and relevant measures will be helpful for corporate green management performance as well as their GC and GPDP [41,114], if it can be applied to GKS behavior among employees. Second, enterprises must intensify the employees' GPPO to make them more engaged in their own work and improve the overall organizational performance through meeting the environmental demands of green consumers and practicing the environmental management concept [115] when environmental awareness is popularized. Finally, enterprises should establish and carry out the blueprint of the green strategies because they could actively allocate and budget resources or develop relevant work designs to promote green management, so that they can achieve the members' GOI, and consequently enhance the degree of the members' organizational identity and GPPO. This combination of corporate governance mode and GOI will be able to further improve the green management performance of enterprises and maintain sustainable development for the environment [116].

\subsection{Strengths and Limitations}

There are still some limitations in this research. First, the data results unexpectedly revealed that GPPO can affect GPDP through knowledge sharing and GC. Such a remote mediating effect has statistical data support. This article presented a preliminary study that should be further examined through relevant literature and theories. Second, the smallor medium-sized enterprises in Taiwan may be different from listed (over-the-counter) companies. Third, this study was conducted based on the precondition that both R\&D and sales staff expect their products to be favored by consumers and discuss GC and GPDP from the perspective of first-line department managers and employees from the R\&D and sales department of companies. This means that personnel from other departments were not included. Fourth, people will affect their knowledge sharing when they feel the pressure of time to reduce their knowledge sharing [117]. This study did not consider the time stress, and future research can be further explored. Finally, the object of this study was selected as Taiwan industrial corporations, whereas other Asian nations like Vietnam, Japan, and Singapore may have differences in their national industries and economic structure.

Author Contributions: T.-W.C. proposed the research framework, ideas and analyzed the results. C.-Z.H. wrote the paper in English. All authors have read and agreed to the published version of the manuscript.

Funding: The authors are grateful for the funding of Ministry of Science and Technology in Taiwan for this study, and the project number of this study is MOST 107-2410-H-606-002.

Conflicts of Interest: The authors declare no conflict of interest. 
Appendix A. Construct Survey Items

\begin{tabular}{|c|c|c|c|}
\hline \multirow{2}{*}{ Constructs } & \multicolumn{2}{|r|}{ Items } & \multirow{2}{*}{ Resources } \\
\hline & Numbers & Content & \\
\hline \multirow{6}{*}{ GOI } & GOI1 & $\begin{array}{l}\text { Top managers, middle managers, and employees of the organization are proud } \\
\text { of its history regarding environmental management and protection. }\end{array}$ & \multirow{6}{*}{ Chen $[20]$} \\
\hline & GOI2 & $\begin{array}{l}\text { Top managers, middle managers, and employees of the organization are proud } \\
\text { of its environmental objectives and missions. }\end{array}$ & \\
\hline & GOI3 & $\begin{array}{l}\text { Top managers, middle managers, and employees think that the organization has } \\
\text { maintained a significant position for environmental management and protection. }\end{array}$ & \\
\hline & GOI4 & $\begin{array}{l}\text { Top managers, middle managers, and employees of the organization think that } \\
\text { the organization has formulated well-defined environmental objectives and } \\
\text { missions. }\end{array}$ & \\
\hline & GOI5 & $\begin{array}{l}\text { Top managers, middle managers, and employees of the organization are } \\
\text { knowledgeable about its environmental tradition and culture. }\end{array}$ & \\
\hline & GOI6 & $\begin{array}{l}\text { Top managers, middle managers, and employees of the organization identify } \\
\text { that it provides considerable attention to environmental management and } \\
\text { protection. }\end{array}$ & \\
\hline \multirow{3}{*}{ GPPO } & GPPO1 & I feel like this green product is mine. & \multirow{3}{*}{ Chang [41] } \\
\hline & GPPO2 & I feel a very high degree of personal ownership of this green product. & \\
\hline & GPPO3 & I feel like I own this green product. & \\
\hline \multirow{5}{*}{ GKS } & GKS1 & $\begin{array}{l}\text { My green knowledge sharing (e.g., eliminating pollution, environmental } \\
\text { protection, and SDGs, etc.) with other organizational members is good. }\end{array}$ & \multirow{5}{*}{$\begin{array}{l}\text { refers to Bock } \\
\text { et al. [54] }\end{array}$} \\
\hline & GKS2 & $\begin{array}{l}\text { My green knowledge sharing (e.g., eliminating pollution, environmental } \\
\text { protection, and SDGs, etc.) with other organizational members is harmful. (R) }\end{array}$ & \\
\hline & GKS3 & $\begin{array}{l}\text { My green knowledge sharing (e.g., eliminating pollution, environmental } \\
\text { protection, and SDGs, etc.) with other organizational members is an enjoyable } \\
\text { experience. }\end{array}$ & \\
\hline & GKS4 & $\begin{array}{l}\text { My green knowledge sharing (e.g., eliminating pollution, environmental } \\
\text { protection, and SDGs, etc.) with other organizational members is valuable to me. }\end{array}$ & \\
\hline & GKS5 & $\begin{array}{l}\text { My green knowledge sharing (e.g., eliminating pollution, environmental } \\
\text { protection, and SDGs, etc.) with other organizational members is a wise move. }\end{array}$ & \\
\hline \multirow{6}{*}{ GC } & GC1 & $\begin{array}{l}\text { The members within the project propose new ways to realize the objectives of } \\
\text { environmental protection. }\end{array}$ & \multirow{6}{*}{$\begin{array}{l}\text { Chen and } \\
\text { Chang [13] }\end{array}$} \\
\hline & GC2 & $\begin{array}{l}\text { The members within the project find out new green ideas to enhance } \\
\text { environmental performance. }\end{array}$ & \\
\hline & GC3 & The members within the project advocate new green ideas to others. & \\
\hline & GC4 & $\begin{array}{l}\text { The members within the project create proper plans for the implementation of } \\
\text { new green ideas }\end{array}$ & \\
\hline & GC5 & The members within the project would recheck new green ideas. & \\
\hline & GC6 & $\begin{array}{l}\text { The members within the project would discover original solutions for } \\
\text { environmental problems. }\end{array}$ & \\
\hline \multirow{5}{*}{ GPDP } & GPDP1 & $\begin{array}{l}\text { The project of green product development contributes significant revenues to the } \\
\text { company. }\end{array}$ & \multirow{5}{*}{$\begin{array}{l}\text { Chen and } \\
\text { Chang [13] }\end{array}$} \\
\hline & GPDP2 & The project invents outstanding green products. & \\
\hline & GPDP3 & The project continues to improve its development processes over time. & \\
\hline & GPDP4 & The project is more creative in green product development than its competitors. & \\
\hline & GPDP5 & The project can achieve its aims in green product development. & \\
\hline
\end{tabular}




\section{References}

1. Naffziger, D.W.; Ahmed, N.U.; Montagno, R.V. Perceptions of environmental consciousness in US small businesses: An empirical study. SAM Adv. Manag. J. 2003, 68, 23-32.

2. Ünal, A.B.; Steg, L.; Gorsira, M. Values versus environmental knowledge as triggers of a process of activation of personal norms for eco-driving. Environ. Behav. 2018, 50, 1092-1118. [CrossRef] [PubMed]

3. Porter, M.E.; van der Linde, C. Green and competitive. Harv. Bus. Rev. 1995, 73, 120-134.

4. Choi, M.; Kim, Y. Antecedents of green purchase behavior: An examination of collectivism, environmental concern, and PCE. Adv. Consum. Res. 2005, 32, 592-599.

5. Bang, H.K.; Ellinger, A.E.; Hadjimarcou, J.; Traichal, P.A. Consumer concern, knowledge, belief, and attitude toward renewable energy: An application of the reasoned action theory. Psychol. Mark. 2000, 17, 449-468. [CrossRef]

6. Xiao, C.; Hong, D. Gender differences in environmental behaviors among the Chinese public: Model of mediation and moderation. Environ. Behav. 2018, 50, 975-996. [CrossRef]

7. Steger, U. The Greening of the Board Room: How German Companies Are Dealing with Environmental Issues in Environmental Strategies for Industry: International Perspectives on Research Needs and Policy Implications; Fischer, K., Schot, J., Eds.; Island Pre: Washington, DC, USA, 1993; pp. 147-166.

8. Brick, C.; Lewis, G.J. Unearthing the "green" personality: Core traits predict environmentally friendly behavior. Environ. Behav. 2016, 48, 635-658. [CrossRef]

9. Chang, T.W.; Chen, F.F.; Luan, H.D.; Chen, Y.S. Effect of green organizational identity, green shared vision, and organizational citizenship behavior for the environment on green product development performance. Sustainability 2019, 11, 617. [CrossRef]

10. Chen, Y.S.; Chang, T.W.; Lin, C.Y.; Lai, P.Y.; Wang, K.H. The influence of proactive green innovation and reactive green innovation on green product development performance: The mediation role of green creativity. Sustainability 2016, 8, 966. [CrossRef]

11. Ghingold, M.; Hall, E.H.; Johnson, B. Intrafirm technical knowledge and competitive advantage: A framework and exploratory study. J. Bus. Strateg. 1998, 15, 108-129.

12. Devanna, M.A.; Tichy, N. Creating the competitive organization of the 21th century: The boundary less corporation. Hum. Resour. Manag. 1990, 29, 445-471. [CrossRef]

13. Chen, Y.S.; Chang, C.H. The determinants of green product development performance: Green dynamic capabilities, green transformational leadership, and green creativity. J. Bus. Ethics 2013, 116, 107-119. [CrossRef]

14. Pfeffer, J. Competitive Advantage through People: Unleashing the Power of the Work Force; Harvard Business School Press: Boston, MA, USA, 1994.

15. Cronin, J.J., Jr.; Smith, J.S.; Gleim, M.R.; Ramirez, E.; Martinez, J.D. Green marketing strategies: An examination of stakeholders and the opportunities they present. J. Acad. Mark. Sci. 2011, 39, 158-174. [CrossRef]

16. Davenport, T.H.; Prusak, L. Working Knowledge: How Organizations Manage What They Know; Harvard Business Press: Cambridge, UK, 1998.

17. Raudeliūnienè, J.; Davidavičienè, V.; Jakubavičius, A. Knowledge management process model. Entrep. Sustain. Issues 2018, 5, 542-554. [CrossRef]

18. Hendricks, P. Why Share Knowledge? The Influence of ICT on the Motivation for Knowledge Sharing. Knowl. Process Manag. 1999, 6, 91-100. [CrossRef]

19. Chen, Y.S.; Lin, S.H.; Lin, C.Y.; Hung, S.T.; Chang, C.W.; Huang, C.W. Improving green product development performance from green vision and organizational culture perspectives. Corp. Soc. Responsib. Environ. Manag. 2020, 27, 222-231. [CrossRef]

20. Chen, Y.S. Green organizational identity: Sources and consequence. Manag. Decis. 2011, 49, 384-404. [CrossRef]

21. Song, W.; Yu, H. Green innovation strategy and green innovation: The roles of green creativity and green organizational identity. Corporate Soc. Responsib. Environ. Manag. 2018, 25, 135-150. [CrossRef]

22. Mittal, S.; Dhar, R.L. Effect of green transformational leadership on green creativity: A study of tourist hotels. Tour. Manag. 2016, 57, 118-127. [CrossRef]

23. Belk, R.W. Possessions and the extended self. J. Consum. Res. 1988, 15, 139-168. [CrossRef]

24. Dittmar, H. The Social Psychology of Material Possessions: To Have Is to Be; St. Martin's Press: New York, NY, USA, 1992.

25. Furby, L. Possessions: Toward a theory of their meaning and function throughout the life cycle. Life-Span Dev. Behav. 1978, 1 , 297-336.

26. Furby, L. Possession in humans: An exploratory study of its meaning and motivation. Soc. Behav. Personal. Int. J. 1978, 6, 49-65. [CrossRef]

27. Isaacs, S. Social development in young children. Br. J. Educ. Psychol. 1933, 3, 291-294. [CrossRef]

28. Kline, L.W.; France, C.J. The psychology of ownership. Pedagog. Semin. 1899, 6, 421-470. [CrossRef]

29. Etzioni, A. The socio-economics of property. J. Soc. Behav. Pers. 1991, 6, 465-468.

30. Pierce, J.L.; Rubenfeld, S.A.; Morgan, S. Employee ownership: A conceptual model of process and effects. Acad. Manag. Rev. 1991, 16, 121-144. [CrossRef]

31. Porteous, J.D. Home: The territorial core. Geogr. Rev. 1976, 66, 383-390. [CrossRef]

32. Scannell, L.; Gifford, R. Place attachment enhances psychological need satisfaction. Environ. Behav. 2017, 49, 359-389. [CrossRef]

33. Hadavi, S. Direct and indirect effects of the physical aspects of the environment on mental well-being. Environ. Behav. 2017, 49, 1071-1104. [CrossRef] 
34. Pierce, J.L.; Kostova, T.; Dirks, K.T. Toward a theory of psychological ownership in organizations. Acad. Manag. Rev. 2001, 26, 298-310. [CrossRef]

35. Pierce, J.L.; Kostova, T.; Dirks, K.T. The state of psychological ownership: Integrating and extending a century of research. Rev. Gen. Psychol. 2003, 7, 84-107. [CrossRef]

36. Pierce, J.L.; Jussila, I. Psychological Ownership and the Organizational Context: Theory, Research Evidence, and Application; Edward Elgar Publishing: Cheltenham, UK, 2011.

37. Jussila, I.; Tarkiainen, A.; Sarstedt, M.; Hair, J.F. Individual psychological ownership: Concepts, evidence, and implications for research in marketing. J. Mark. Theory Pract. 2015, 23, 121-139.

38. Qian, X. New Research Progress Review on Psychological Ownership. Open J. Soc. Sci. 2016, 4, 155-160. [CrossRef]

39. Chiu, W.C.K.; Hui, C.H.; Lai, G.W. Psychological ownership and organizational optimism amid China's corporate transformation: Effects of an employee ownership scheme and a management-dominated board. Int. J. Hum. Resour. Manag. 2007, 18, 303-320. [CrossRef]

40. Beggan, J.K. On the social nature of nonsocial perception: The mere ownership effect. J. Pers. Soc. Psychol. 1992, 62, 229-237. [CrossRef]

41. Chang, T.W. Corporate Sustainable Development Strategy: Effect of Green Shared Vision on Organization Members' Behavior. Int. J. Environ. Res. Public Health 2020, 17, 2446. [CrossRef]

42. Van Dyne, L.; Pierce, J.L. Psychological ownership and feelings of possession: Three field studies predicting employee attitudes and organizational citizenship behavior. J. Organ. Behav. 2004, 25, 439-459. [CrossRef]

43. Mustafa, M.; Ramos, H.M.; Man, T.W.Y. Linking psychological ownership to employee extra-role behaviors in small overseas Chinese family businesses: Does family status matter? J. Entrep. Emerg. Econ. 2015, 7, 129-147.

44. Pujari, D.; Wright, G.; Peattie, K. Green and competitive: Influences on environmental new product development performance. J. Bus. Res. 2003, 56, 657-671. [CrossRef]

45. Albino, V.; Balice, A.; Dangelico, R.M. Environmental strategies and green product development: An overview on sustainabilitydriven companies. Bus. Strategy Environ. 2009, 18, 83-96. [CrossRef]

46. Hunt, S.D.; Morgan, R.M. The comparative advantage theory of competition. J. Mark. 1995, 59, 1-15. [CrossRef]

47. Dahooie, J.H.; Afrazeh, A.; Hosseini, S.M.M. An activity-based framework for quantification of knowledge work. J. Knowl. Manag. 2011, 15, 422-444. [CrossRef]

48. Nancy, M.D. Common Knowledge: How Companies Thrive by Sharing What They Know, 1st ed.; Harvard Business School Press: Boston, MA, USA, 2000.

49. Han, T.S.; Chiang, H.H.; Chang, A. Employee participation in decision making, psychological ownership and knowledge sharing: Mediating role of organizational commitment in Taiwanese high-tech organizations. Int. J. Hum. Resour. Manag. 2010, 21, 2218-2233. [CrossRef]

50. Yuan, Z.; Li, Y.; Tetrick, L.E. Job hindrances, job resources, and safety performance: The mediating role of job engagement. Appl. Ergon. 2015, 51, 163-171. [CrossRef] [PubMed]

51. Senge, P. Sharing Knowledge. Exec. Excell. 1997, 15, 11-12.

52. Darr, E.D.; Kurtzberg, T.R. An investigation of partner similarity dimensions on knowledge transfer. Organ. Behav. Hum. Dicision Process. 2000, 82, 28-44. [CrossRef]

53. Wijnhoven, F. Knowledge logistic in business contexts: Analyzing and diagnosing knowledge sharing by logistics concepts. Knowl. Process Manag. 1998, 5, 143-157. [CrossRef]

54. Bock, G.W.; Zmud, R.W.; Kim, Y.G.; Lee, J.N. Behavioral intention formation in knowledge sharing: Examining the roles of extrinsic motivators, social-psychological forces, and organizational climate. MIS Q. 2005, 29, 87-112. [CrossRef]

55. Schwaer, C.; Biemann, T.; Voelpel, S. Antecedents of employee's preference for knowledge-sharing tools. Int. J. Hum. Resour. Manag. 2012, 23, 3613-3635. [CrossRef]

56. Wang, S.; Noe, R.A. Knowledge sharing: A review and directions for future research. Hum. Resour. Manag. Rev. 2010, $20,115-131$. [CrossRef]

57. Cummings, J.N. Work groups, structural diversity, and knowledge sharing in a global organization. Manag. Sci. 2004, 50, 352-364. [CrossRef]

58. Foss, N.J.; Minbaeva, D.B.; Pedersen, T.; Reinholt, M. Encouraging knowledge sharing among employees: How job design matters. Hum. Resour. Manag. 2009, 48, 871-893. [CrossRef]

59. Zaim, H.; Muhammed, S.; Tarim, M. Relationship between knowledge management processes and performance: Critical role of knowledge utilization in organizations. Knowl. Manag. Res. Pract. 2019, 17, 24-38. [CrossRef]

60. Hidding, G.; Shireen, M.C. Anatomy of a Learning Organization: Turning Knowledge into Capital at Andersen Consulting. Knowl. Process Manag. 1998, 5, 3-13. [CrossRef]

61. Nonaka, I.; Takeuchi, H. The Knowledge Creating Company; Oxford University Press: New York, NY, USA, 1995.

62. Cross, R.; Parker, A. The Hidden Power Social Networks; Harvard Business School Press: Boston, MA, USA, 2004.

63. Yli-Renko, H.; Autio, E.; Sapienza, H.J. Social capital, knowledge acquisition, and knowledge exploitation in young technologybased firms. Strateg. Manag. J. 2001, 22, 587-613. [CrossRef]

64. Amabile, T.M. A model of creativity and innovation in organizations. Res. Organ. Behav. 1988, 10, $123-167$. 
65. Liao, S.H.; Chang, J.C.; Cheng, S.C.; Kuo, C.M. Employee relationship and knowledge sharing: A case study of a Taiwanese finance and securities firm. Knowl. Manag. Res. Pract. 2004, 2, 24-34. [CrossRef]

66. Brazeal, D.V.; Herbert, T.T. The genesis of entrepreneurship. Entrep. Theory Pract. 1999, 23, 29-46. [CrossRef]

67. Cheng, J.H.; Huang, J.K.; Zhao, J.F.; Wu, P. Open innovation: The role of organizational learning capability, collaboration and knowledge sharing. Int. J. Organ. Innov. 2019, 11, 260-272.

68. Abukhait, R.M.; Bani-Melhem, S.; Zeffane, R. Empowerment, knowledge sharing and innovative behaviours: Exploring gender differences. Int. J. Innov. Manag. 2018, 23, 1950006. [CrossRef]

69. Wang, J.; Yang, J.; Xue, Y. Subjective well-being, knowledge sharing and individual innovation behavior: The moderating role of absorptive capacity. Leadersh. Organ. Dev. J. 2017, 38, 1110-1127. [CrossRef]

70. Mura, M.; Lettieri, E.; Radaelli, G.; Spiller, N. Promoting professionals' innovative behaviour through knowledge sharing: The moderating role of social capital. J. Knowl. Manag. 2013, 17, 527-544. [CrossRef]

71. Chen, M.H.; Wang, H.Y.; Wang, M.C. Knowledge sharing, social capital, and financial performance: The perspectives of innovation strategy in technological clusters. Knowl. Manag. Res. Pract. 2018, 16, 89-104. [CrossRef]

72. Thornhill, S. Knowledge, innovation and firm performance in high-and low technology regimes. J. Bus. Ventur. 2006, 21, 687-703. [CrossRef]

73. Sosa, M.E. Where do creative interactions come from? The role of tie content and social networks. Organ. Sci. 2011, 22, 1-21. [CrossRef]

74. Kremer, H.; Villamor, I.; Aguinis, H. Innovation leadership: Best-practice recommendations for promoting employee creativity, voice, and knowledge sharing. Bus. Horiz. 2019, 62, 65-74. [CrossRef]

75. Amabile, T.M. Creativity in Context; Westview Press: Boulder, CO, USA, 1996.

76. Florea, L.; Cheung, Y.H.; Herndon, N.C. For all good reasons: Role of values in organizational sustainability. J. Bus. Ethics 2013, 114, 393-408. [CrossRef]

77. Tierney, P.; Farmer, S.M.; Graen, G.B. An examination of leadership and employee creativity: The relevance of traits and relationships. Pers. Psychol. 1999, 52, 591-620. [CrossRef]

78. Woodman, R.W.; Sawyer, J.E.; Griffin, R.W. Toward a theory of organizational creativity. Acad. Manag. Rev. 1993, 18, $293-321$. [CrossRef]

79. Shalley, C.E.; Gilson, L.L. What leaders need to know: A review of social and contextual factors that can foster or hinder creativity. Leadersh. Q. 2004, 15, 33-53. [CrossRef]

80. Barczak, G.; Lassk, F.; Mulki, J. Antecedents of team creativity: An examination of team emotional intelligence, team trust and collaborative culture. Creat. Innov. Manag. 2010, 19, 332-345. [CrossRef]

81. Osterloh, M.; Frey, B.S. Motivation, knowledge transfer, and organizational forms. Organ. Sci. 2000, 11, 538-550. [CrossRef]

82. Griffin, A.; Page, A.L. PDMA success measurement project: Recommended measures for product development success and failure. J. Prod. Innov. Manag. 1996, 13, 478-496. [CrossRef]

83. Chen, Y.S. The drivers of green brand equity: Green brand image, green satisfaction, and green trust. J. Bus. Ethics 2010, 93, 307-319. [CrossRef]

84. Halbesleben, J.R.B.; Novicevic, M.M.; Harvey, M.G.; Buckley, M.R. Awareness of temporal complexity in leadership of creativity and innovation: A competency-based model. Leadersh. Q. 2003, 14, 433-454. [CrossRef]

85. Chang, C.H. The influence of corporate environmental ethics on competitive advantage: The mediation role of green innovation. J. Bus. Ethics 2011, 104, 361-370. [CrossRef]

86. Deshpande, R.; Farley, J.U.; Webster, F.E. Corporate culture, customer orientation, and innovativeness. J. Mark. 1993, 57, $23-37$. [CrossRef]

87. Zhang, B.Y.; Li, J. Design for environmental protection: Measuring the appeal factors of green product for consumers. Ekoloji 2019, 28, 1699-1707.

88. Albert, S.; Whetten, D.A. Research in Organizational Behavior; JAI Press: Greenwich, CT, USA, 1985.

89. Dutton, J.E.; Dukerich, J.M. Keeping an eye on the mirror: Image and identity in organizational adaptation. Acad. Manag. J. 1991, 34, 517-554.

90. Pervin, L.A. Persons, situations, interactions: The history of a controversy and a discussion of theoretical models. Acad. Manag. Rev. 1989, 14, 350-360. [CrossRef]

91. Ghoshal, S.; Bartlett, C.A. Linking organizational context and managerial action: The dimensions of quality of management. Strateg. Manag. J. 1994, 15, 91-112. [CrossRef]

92. Byron, K. A meta-analytic review of work-family conflict and its antecedents. J. Vocat. Behav. 2005, 67, 169-198. [CrossRef]

93. Ashforth, B.E.; Mael, F. Social identity theory and the organization. Acad. Manag. Rev. 1989, 14, 20-39. [CrossRef]

94. Cheney, G. On the various and changing meaning of organizational membership: A field study of organizational identification. Commun. Monogr. 1983, 50, 342-362. [CrossRef]

95. Feather, N.T.; Rauter, K.A. Organizational citizenship behaviors in relation to job status, job insecurity, organizational commitment and identification, job satisfaction and work values. J. Occup. Organ. Psychol. 2004, 77, 81-94. [CrossRef]

96. Lee, E.S.; Park, T.Y.; Koo, B. Identifying organizational identification as a basis for attitudes and behaviors: A meta-analytic review. Psychol. Bull. 2015, 141, 1049-1080. [CrossRef] 
97. Bao, G.; Xu, B.; Zhang, Z. Employees' trust and their knowledge sharing and integration: The mediating roles of organizational identification and organization-based self-esteem. Knowl. Manag. Res. Pract. 2016, 14, 362-375. [CrossRef]

98. Rosendaal, B.; Bijlsma-Frankema, K. Knowledge sharing within teams: Enabling and constraining factors. Knowl. Manag. Res. Pract. 2015, 13, 235-247. [CrossRef]

99. Sethi, R. New product quality and product development teams. J. Mark. 2000, 64, 1-14. [CrossRef]

100. Benet-Martínez, V.; Leu, J.; Lee, F.; Morris, M.W. Negotiating biculturalism: Cultural frame switching in biculturals with oppositional versus compatible cultural identities. J. Cross-Cult. Psychol. 2002, 33, 492-516. [CrossRef]

101. Dougherty, D. Understanding new markets for new products. Strateg. Manag. J. 1990, 11, 59-78.

102. Geraie, M.S.; Rad, F.M. Mediator role of the organizational identity green in relationship between total quality management and perceived innovation with sustainable competitive advantage. Int. J. Biol. Pharm. Allied Sci. 2015, 4, $266-276$.

103. Maas, C.J.; Hox, J.J. Sufficient sample sizes for multilevel modeling. Methodology 2005, 1, 86-92. [CrossRef]

104. Hair, J.; Anderson, R.; Tatham, R.; Black, W. Multivariate Data Analysis; Prentice-Hall: Upper Saddle River, NJ, USA, 1998.

105. Bagozzi, R.P.; Yi, Y. On the evaluation of structural equation models. J. Acad. Mark. Sci. 1988, 16, 74-94. [CrossRef]

106. Fornell, C.; Larcker, D.F. Structural equation models with unobservable variables and measurement error: Algebra and statistics. J. Mark. Res. 1981, 18, 382-388. [CrossRef]

107. James, L.R. Aggregation Bias in Estimates of Perceptual Agreement. J. Appl. Psychol. 1982, 67, 219-229. [CrossRef]

108. Glick, W.H. Conceptualizing and measuring organizational and psychological climate: Pitfalls in multilevel research. Acad. Manag. Rev. 1985, 10, 601-616. [CrossRef]

109. Ostroff, C.; Schmitt, N. Configurations of organizational effectiveness and efficiency. Acad. Manag. J. 1993, 36, $1345-1361$.

110. George, J.M.; Bettenhausen, K. Understanding prosocial behavior, sales performance, and turnover: A group-level analysis in a service context. J. Appl. Psychol. 1990, 75, 698. [CrossRef]

111. Baron, R.M.; Kenny, D.A. The moderator-mediator variable distinction in social psychological research: Conceptual, strategic, and statistical considerations. J. Personal. Soc. Psychol. 1986, 51, 1173-1182. [CrossRef]

112. Taylor, A.B.; MacKinnon, D.P.; Tein, J.Y. Tests of the three-path mediated effect. Organ. Res. Methods 2008, 11, 241-269. [CrossRef]

113. Zhang, Z.; Sundaresan, S. Knowledge markets in firms: Knowledge sharing with trust and signalling. Knowl. Manag. Res. Pract. 2010, 8, 322-339. [CrossRef]

114. Chang, T.W.; Yeh, Y.L.; Li, H.X. How to Shape an Organization's Sustainable Green Management Performance: The Mediation Effect of Environmental Corporate Social Responsibility. Sustainability 2020, 12, 9198. [CrossRef]

115. Chang, T.W.; Wang, K.H.; Lin, Y.H. Corporate Sustainability: It's Mine! Effect of Green Product Psychological Ownership on the Environmental Behavior and Performance of Employees. Sustainability 2020, 12, 10514. [CrossRef]

116. Connelly, C.E.; Ford, D.P.; Turel, O.; Gallupe, B.; Zweig, D. 'I'm busy (and competitive)!' Antecedents of knowledge sharing under pressure. Knowl. Manag. Res. Pract. 2014, 12, 74-85. [CrossRef]

117. Chang, T.W.; Chen, Y.S.; Yeh, Y.L.; Li, H.X. Sustainable consumption models for customers: Investigating the significant antecedents of green purchase behavior from the perspective of information asymmetry. J. Environ. Plan. Manag. 2020, 1-21. [CrossRef] 